\title{
CUTTING ENERGY REQUIRED DURING THE MECHANICAL PROCESSING OF WOOD SPECIES AT DIFFERENT DRYING STAGES
}

\author{
Taiane Oliveira Guedes ${ }^{1, \$}$, José Reinaldo Moreira da Silva ${ }^{1}$, Paulo Ricardo Gherardi Hein ${ }^{1}$, \\ Silvia Costa Ferreira ${ }^{2}$
}

\begin{abstract}
The aim of this study was to know the variation profile of the specific energy consumption required to cut woods with varying densities and moisture contents. Therefore, peripheral cuts were performed in the longitudinal direction of the grain with numerical control controlled by Computational Numerical Command in woods of different densities, established at different drying stages. An energy analyzer, capable of calculate the specific energy consumed during the wood processing, was used to measure the energy information. The results indicated that the higher the wood density, the greater the positive influence of the moisture content on the specific cutting energy. In the anhydrous condition, the higher the wood density, the higher the cutting energy. With increased moisture content, less cutting power was required during the wood processing. Therefore, it was possible to conclude that during the milling type mechanical processing of wood, moisture content has a great influence on the specific cutting energy consumption.
\end{abstract}

Keywords: Basic density, CNC, energy analyzer, moisture content, wood processing.

\section{INTRODUCTION}

The mechanical processing of wood requires knowledge of the material particularities in order to obtain quality products with greater efficiency. According to Ma et al. (2014), machining processes need to be evaluated and optimized as a way to propel them towards a future sustainable manufacturing.

The specific energy required when cutting wood is an important variable to be evaluated, ensuring that the machines are being efficient during the mechanical processing, avoiding energy waste and overloads, that cause the production to be interrupted (technical stops) by exceeding the request limits of motors.

The energy consumed is influenced by the processing variables, such as cutting speed and feed rate, as well as by the internal structure of the wood. It is known that the wood properties, especially density, directly affect the forces required for cutting (Koch 1964). The grayscale imaging technique has shown that density is correlated with the forces required for cutting (Axelsson et al. 1993). The wood moisture content also affects its processing, so the higher the moisture content, the lower the cutting force required (Franz 1958, Mckenzie 1961 and Koch 1964).

However, many studies differ regard to the relationship between moisture content of the wood and its processing. Chardin (1954) indicated that the increase in moisture content decreases the force required for cutting,

\footnotetext{
${ }^{1}$ Department of Forest Science, Federal University of Lavras (UFLA), Lavras, Brazil.

${ }^{2}$ Department of Engineer, Federal University of Lavras (UFLA), Brazil.

"Corresponding author: guedestaiane@gmail.com

Received: 23.03.2019 Accepted: 18.06.2020
} 
but only for species with low density. Loehnertz and Cooz (1998) stated that the relationship between moisture content and force required depends on the species studied. As for Pinus sylvestris, with increasing moisture content, the average cutting forces initially decreased and then stabilized (Zhu et al. 2019).

Studies related to cutting energy consumption are reported with variations in the genetic material (Melo et al. 2016), in the machine parameters (Souza et al. 2011) and in the moisture content (Nascimento et al. 2017), in which the specific energy is obtained with a frequency inverter in a circular saw. In addition, there are studies in scientific literature that relate the influence of wood mechanical strength on its mechanical processing.

Cutting forces can be predicted by physical and mechanical characteristics of the wood (Eyma et al. 2004). In a study by Günay et al. (2005), the authors found the angles of the cutting tool can influence the force required for cutting and the cutting force can be reduced by increasing the angle of inclination during machining. Machining parameters were evaluated to study cutting force and energy (Barcík et al. 2008). Different levels of moisture content were tested for their influence on cutting, along with mechanical evaluation (Naylor et al. 2012). Interactions were found between the machining parameters and the mechanical properties of wood (Mandić et al. 2015). However, to date, there are no researches that measure the magnitude with which these properties interfere with the energy required during processing. Studies that correlate the specific cutting energy required with different wood moisture content values are lacking.

The use of technology that allows a better control of the mechanical processing is fundamental to improve results in this sector. Machines controlled by Computational Numerical Command (CNC) provide greater precision, shorter cutting time and the execution of operations with previously determined parameters, making it possible the repeatability and the reproducibility of the tests.

This configuration allows the study of variations to be relevant only to the raw material. With the use of the $\mathrm{CNC}$, it is possible to establish some process parameters, such as cutting speeds and depths, and keep them unchanged. This function allows all the variations to be attributed only to the raw material when monitoring the mechanical processing, as occurs in this study.

The aim of this research was to evaluate and quantify the energy required in the mechanical processing of woods with different densities (high, medium, and low) and different moisture content.

\section{MATERIAL AND METHODS}

\section{Mechanical processing}

Resinous timbers of Pinus taeda with basic density of $\rho=368 \mathrm{~kg} / \mathrm{m}^{3}$, broad-leafed Goupia glabra with basic density of $\rho=717 \mathrm{~kg} / \mathrm{m}^{3}$ and broad-leafed Dipteryx alata with basic density of $\rho=914 \mathrm{~kg} / \mathrm{m}^{3}$ were used for contrasting densities, being considered as low, medium and high-density woods, respectively (Forest Products Laboratory 1973). The mechanical processing of the wood was carried out by a router (model: GOF 1300 $\mathrm{CE}, \mathrm{BOSCH}$ ) with $1300 \mathrm{~W}$ of power, controlled by Computational Numerical Command (CNC), with a $6 \mathrm{~mm}$ diameter milling cutter, $0,70 \mathrm{~m} / \mathrm{min}$, penetration speed of $200 \mathrm{~mm} / \mathrm{min}$ and cutting speed of $3,77 \mathrm{~m} / \mathrm{s}$.

The drying process, in the initial phase, was carried outdoors until the material reached the equilibrium moisture (12\%), and then it was dried in the kiln to achieve anhydrous condition. Peripheral longitudinal cuts $\left(90^{\circ}-0^{\circ}\right) 200 \mathrm{~mm}$ long, $6 \mathrm{~mm}$ wide and $3 \mathrm{~mm}$ deep were made in the wood samples (Figure 1), which were initially wet, above the FSP (Fiber Saturation Point), being considered for this study as saturated samples. The drying, in the initial phase, was carried outdoors until reaching equilibrium moisture (12\%). Subsequently was carried drying in the kiln to achieve anhydrous condition. Each sample was processed in the respective drying stages: saturated, equilibrium and anhydrous. The moisture content was determined by ABNT NBR 7190 (2010) on a dry basis.

At all drying stages the cutting energies were monitored and the required electrical power was obtained by the energy analyzer (Fluke, model 435, Fluke Corporation, Everett, USA). 




Figure 1: Mechanical processing done with a router. (a) End mill cutter on wood samples. (b) Wood samples of the three species after milling. (c) Outline of the specimen after consecutive cuts of the milling machine.

Six samples of each species were used, cut five times (Figure 1) in each drying stage (saturated, equilibrium and anhydrous) totaling thirty cuts for the energy consumption was collected.

\section{Acquisition of the electric energy data}

To measure the voltage and current during wood mechanical processing, two test leads with a capacity of $600 \mathrm{~V}$ and $20 \mathrm{~A}$ were connected to the router. With the energy analyzer (Figure 2), the data of maximum, average and minimum active power $(\mathrm{kW})$ required by the router were obtained over the cutting time $(\mathrm{s})$. The equipment acquires the electrical variables uninterruptedly, generating power values every $0,5 \mathrm{~s}$ the minimum time required by the analyzer to adequately obtain the active power.

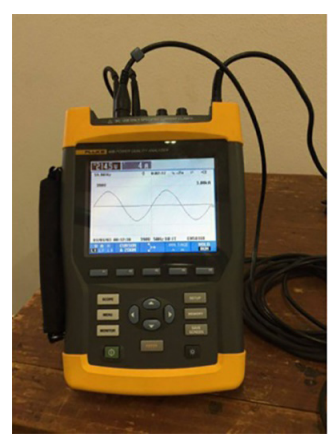

Figure 2: Specific cutting energy calculation.

Inactive energy, when the engine is not cutting, is not accounted for in this calculation. The energy analyzer uses only the active energy consumed during the cut.

\section{Calculation of specific cutting energy}

The volume of material removed, the active power and the cutting time were used to determine the specific cutting energy (Es), according to Equation 1. The active power was obtained by the energy analyzer and the volume of material removed was calculated based on milled cut diameter, penetration depth and cut length. For the calculation of the specific cutting energy in the interval of 3 seconds, the cutting execution time, the average values of active power provided by the energy analyzer were considered. The energy consumed was obtained through the numerical integral (Pantaleo and Pellerano, 2013).

$$
E S=\frac{\int_{t_{1}}^{t_{2}} P(t) d t}{V}
$$

Where:

$E_{s}=$ Specific cutting energy $\left(\mathrm{kJ} / \mathrm{cm}^{3}\right)$ 


$$
\begin{aligned}
& P(t)=\text { Power active at time } t \text { (Watt) } \\
& t=\text { time }(\mathrm{s}) \\
& V=\text { Volume }\left(\mathrm{cm}^{3}\right)
\end{aligned}
$$

The data obtained for the cutting energy consumption $\left(\mathrm{kJ} / \mathrm{cm}^{3}\right)$ were taken around the saturation point of the fibers until the wood was completely dry.

\section{RESULTS AND DISCUSSION}

Table 1 show in overall the specific cutting energy consumption values of the three species.

Table 1: Descriptive statistics of the values referring to the specific cutting energy consumption of the three species during mechanical processing at all drying stages.

\begin{tabular}{|c|c|c|c|c|}
\hline \multirow{2}{*}{ Species } & \multicolumn{4}{|c|}{ Specific cutting energy $\left(\mathrm{kJ} \cdot \mathrm{cm}^{-3}\right)$} \\
\cline { 2 - 5 } & \multirow{2}{*}{ Maximum } & Minimum & Average & Standard deviation \\
\hline Pinus taeda & 513 & 344 & 406 & 48,45 \\
\hline Goupia glabra & 567 & 365 & 429 & 48,12 \\
\hline Dipteryx alata & 551 & 290 & 435 & 78,09 \\
\hline
\end{tabular}

Figure 3 presents the distribution of energy consumption for each density as a function of moisture content.

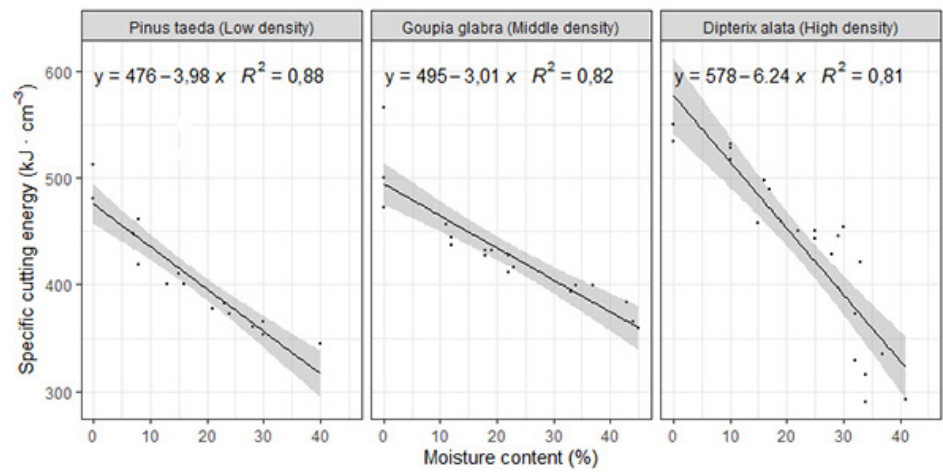

Figure 3: Behavior of specific cutting energy with moisture content variation for species of three densities.

From Figure 3, the specific cutting energy consumption of the wood from above the FSP until complete drying can be analyzed. The three wood species presented the same behavior, although at different magnitudes. In the anhydrous condition ( $0 \%$ moisture content), the higher the wood density, the higher the energy required for processing. In this sense, Dipteryx alata wood required $570 \mathrm{~kJ} / \mathrm{cm}^{3}, 14,7 \%$ higher than the energy required by Pinus taeda wood, which required $497 \mathrm{~kJ} / \mathrm{cm}^{3}$. Pinus taeda wood, of low density $\left(368 \mathrm{~kg} / \mathrm{m}^{3}\right)$, presented an increase from 291 to $497 \mathrm{~kJ} / \mathrm{cm}^{3}(70,2 \%$ ) when underwent a reduction in moisture content from $85 \%$ (saturated condition) to $0 \%$ (anhydrous condition). In the processing of Goupia glabra $\left(717 \mathrm{~kg} / \mathrm{m}^{3}\right)$, the specific cutting energy increased from 261 to $513 \mathrm{~kJ} / \mathrm{cm}^{3}(9 \%)$ with a $71 \%$ reduction in moisture content. For Dipterix alata, the densest wood species $\left(914 \mathrm{~kg} / \mathrm{m}^{3}\right)$, the specific cutting energy increased from 290 to $551 \mathrm{~kg} / \mathrm{m}^{3}(90 \%)$, with a moisture content reduction from $41 \%$ to $0 \%$.

For the three wood species there was an indirect correlation between moisture content and energy consumption: the higher the moisture content, the lower the energy consumption. The density was a factor that defined the influence of moisture content on energy consumption: the densest wood species showed the greatest variation in consumption during drying, followed by the medium and low densities. 
It is known that the amount of water inside the cell wall interferes with its resistance (Glass and Zelinka 2010) and lower energy is required during wood processing. Higher density woods are more sensitive to changes until they reach equilibrium moisture content (Hernández 2007). Thus, it was observed that the higher the wood density, the greater its capacity to desorbs water and that the higher the amount of water inside the cell wall, the less energy is required during processing.

In the equilibrium condition, the variation in specific cutting energy between species was low. That means that when the wood is processed in hygroscopic balance, there is little variation in the specific cutting energy.

The energy required for wood processing and the wood moisture content correlated significantly, presenting satisfactory values for coefficient of determination. The cutting energy presented a negative relation with the moisture content, showing that as the wood was dried, the energy requirement for its cut increased. The magnitude of the relation between these variables depends on the wood density.

\section{CONCLUSIONS}

The moisture content presented a positive and indirect relation to specific cutting energy consumption. For the saturated condition, the specific cutting energy consumption decreased by an average of $38 \%$.

Wood density had a positive relation with energy consumption. The highest consumption was required by the densest wood species.

The generated coefficient of determination $\left(\mathrm{R}^{2}>0,8\right)$ attests that the models in which the moisture content explains the behavior of the specific cutting energy consumption are reliable.

\section{ACKNOWLEDGEMENTS}

This study was financed in part by the Coordenação de Aperfeiçoamento de Pessoal de Nível Superior Brasil (CAPES) - Finance Code 001.

\section{REFERENCES}

ABNT. NBR. 2010. Projeto de estruturas de madeira. ABNT. NBR 7190. 2010. Rio de Janeiro, Brazil 50p.

Axelsson, B.; Lundberg, S.; Grönlund, A. 1993. Studies of the main cutting force at and near a cutting edge. Holz als Roh- und Werkstoff 51(1): 43-48. https://doi.org/10.1007/BF02615376

Barcík, Š.; Pivuloskova, E.; Kminiak, R. 2008. Effect of technological parameters and wood properties on cutting power in plane milling of juvenilie poplar wood. Drvna Industrija 59(3): 107-112. https://hrcak.srce.hr/29380

Chardin, A. 1954. Peut-on scier tous les bois avec la même denture. Bois et Forets des Tropiques 33(33): 41-50. https://revues.cirad.fr/index.php/BFT/article/view/18559/18318

Eyma, F.; Méaysoone, P.; Martin, P. 2004. Study of the properties of thirteen tropical wood species to improve the prediction of cutting forces in mode B. Annals of Forest Science 61(1): 55-64. https://www.afs-journal.org/articles/forest/pdf/2004/01/F4106.pdf

Forest Products Laboratory. 1973. Standard terms for describing wood (USDA). Forest Products Laboratory Research Paper. Madison. 14p. https://www.fpl.fs.fed.us/documnts/fplrn/fplrn171.pdf

Franz, N.C. 1958. An analysis of the wood cutting process. $\mathrm{PhD}$ thesis, University of Michigan Press (January 1), 166p. Ann Arbor, Michigan, USA. ISBN-13: 978-0472751426 
https://doi.org/10.3998/mpub.9690780

Glass, S.V.; Zelinka, S.L. 2010. Moisture relations and physical properties of wood. Wood handbook: wood as an engineering material: chapter 4. General technical report FPL; GTR-190. Madison, Centennial ed: WI. p. 4.1-4.19. https://www.fs.usda.gov/treesearch/pubs/37428

Günay, M.; Korkut, I.; Aslan, E.; Şeker, U. 2005. Experimental investigation of the effect of cutting tool rake angle on main cutting force. Journal of Materials Processing Technology 166(1): 44-49. https://doi.org/10.1016/j.jmatprotec.2004.07.092

Hernández, R.E. 2007. Influence of accessory substances, wood density and interlocked grain on the compressive properties of hardwoods. Wood Science and Technology 41: 249. https://doi.org/10.1007/s00226-006-0114-5

Koch, P. 1964. Wood Machining Processes. Finland Institute for Technical Research. New York: Ronald Press. ISBN-13: 978-0826050755. 530p.

Loehnertz, S.P.; Cooz, I.V. 1998. Sawtooth forces in cutting tropical hardwoods native to South America. Madison, WI: US Department of Agriculture, Forest Service, Forest Products Laboratory, 16 p. https://www.fpl.fs.fed.us/documnts/fplrp/fplrp567.pdf

Ma, J.; Ge, X.; Chang, S.I.; Lei, S. 2014. Assessment of cutting energy consumption and energy efficiency in machining of 4140 steel. The International Journal of Advanced Manufacturing 74(9-12): 1701-1708. https://doi.org/10.1007/s00170-014-6101-3

Mandić, M.; Porankiewicz, B.; Danon, G. 2015. An Attempt at Modelling of Cutting Forces in Oak Peripheral Milling. BioResources 10(3): 5489-5502. https://ojs.cnr.ncsu.edu/index.php/BioRes/article/view/ BioRes_10_3_5489_Mandic_Modelling_Cutting_Forces_Oak

Mckenzie, W.M. 1961. Fundamental analysis of the wood-cutting process. PhD thesis, Department of Wood Technology, School of Natural Resources, University of Michigan, Ann Arbor, USA 164 p. https://deepblue.lib.umich.edu/handle/2027.42/6536

Melo, L.E.L.; Da Silva, J.R.M.; Napoli, A.; Lima, J.T.; Trugilho, P.F.; Nascimento, D.F.R. 2016. Influence of genetic material and radial position on the anatomical structure and basic density of wood from Eucalyptus spp. and Corymbia citriodora. Scientia Forestalis 44(111): 611-621. https://www.ipef.br/publicacoes/scientia/nr111/cap07.pdf

Nascimento, R.F.D.; Melo, L.E.E.; Silva, M.R.J, Trugilho; F.P. Napoli, A. 2017. Effect of moisture content on specific cutting energy consumption in Corymbia citriodora and Eucalyptus urophylla woods. Scientia Forestalis 45(113): 221-227. http://dx.doi.org/10.18671/scifor.v45n113.22

Naylor, A.; Hackney, P.; Perera, N.; Clahr, E. 2012. A predictive model for the cutting force in wood machining developed using mechanical properties. BioResources 7(3): 2883-2894. https://ojs.cnr.ncsu.edu/ index.php/BioRes/article/view/2756

Pantaleo, A.; Pellerano, A. 2013. Assessment of wood particleboards milling by means of energy consumption tests. Wood Material Science \& Engineering 9(4): 193-201. https://doi.org/10.1080/17480272.2013.847494

Souza, E.M.D.; Silva, J.R.M.D.; Lima, J.T.; Napoli, A.; Raad, T.J.; Gontijo, T.G. 2011. Specific cutting energy consumption in a circular saw for Eucalyptus stands VM01 and MN463. Cerne 17(1): 109-115. https://doi.org/10.1590/S0104-77602011000100013

Zhu, Z.; Buck, D.; Ekevad, M.; Marklund, B.; Guo, X.; Cao, P.; Zhu, N. 2019. Cutting forces and chip formation revisited based on orthogonal cutting of Scots pine. Holzforschung 73(2): 131-138. https://doi.org/10.1515/hf-2018-0037 